\title{
The impact of using of a DWHR heat exchanger on operating costs for a hot water preparation system and the amount of carbon dioxide emissions entering the atmosphere
}

\author{
Aleksandra Mazur ${ }^{1, *}$ \\ ${ }^{1}$ Rzeszów University of Technology, Faculty of Civil and Environmental Engineering and \\ Architecture, Department of Infrastructure and Sustainable Development, al. Powstańców Warszawy \\ 12, 35-959 Rzeszów, Poland
}

\begin{abstract}
The article analyzes the annual operating costs for several hot water preparation systems and their impact on the environment; also estimating the emission of pollutants, mainly carbon dioxide $\mathrm{CO}_{2}$, which enters the atmosphere as a result of the use of heating installations. The article also investigated the impact of installing a DWHR heat exchanger on a sewage system, draining graywater from the shower on the annual operating costs incurred by users of hot water supply installations. For each heat source an alternative variant was adopted, in which the installation was additionally equipped with a heat exchanger. The amount of annual savings resulting from the installation of a vertical DWHR heat exchanger was determined, depending on the heat source for the hot water preparation system and the duration of the shower bath per one inhabitant. For the same dependencies, the level of reduction of carbon dioxide emissions into the atmosphere was also determined, as a positive effect of using the installation with a heat exchanger.
\end{abstract}

\section{Introduction}

The constantly growing energy needs of the world with the decreasing deposits of nonrenewable raw materials $[1,2]$, and the progressive pollution of the natural environment affecting adverse climate change [3, 4] have drawn attention to further development directions mainly in the energy sector in line with the idea of sustainable development. The concept of sustainable development does not only refer to the rational management of nonrenewable energy resources, or to the protection of Earth's natural resources, but it is also appropriate water and sewage management and the proper operation of infrastructure systems [5-10]. The use of these systems, above all the heating installations, is related to the emission of harmful chemical compounds into the environment. Energy production based on the combustion of fossil fuels is associated with the formation of by-products such as carbon dioxide, nitrogen and sulfur oxides [11] as well as solid fuels and ashes [12]. The European

\footnotetext{
* Corresponding author: a.mazur@prz.edu.pl
} 
Union (EU) Joint Research Center (JRC) has developed a report on global $\mathrm{CO}_{2}$ emissions, which shows that up to $90 \%$ of carbon dioxide released into the atmosphere from the world originates from the combustion of fossil fuels [13]. The way to reduce the consumption of conventional energy as well as limit the negative impact of the use of installation systems on the environment is even just the use of highly effective heating systems or installations that save water, such as graywater recycling $[14,15]$, but above all installations using renewable energy sources $[16,17]$.

Another way in which to reduce the consumption of conventional energy as well as limit the negative impact of the use of heating systems on the natural environment may be the use of installations for heat recovery from graywater [18]. The efficiency of heat recovery systems, as well as the profitability of their use is the subject of many scientific publications due to the enormous potential of using wastewater as a source of energy [19-21]. It is estimated that even 3,5 kWh of energy per person per day can be recovered from waste sources [22]; and the use of waste energy recovery systems from graywater is justified in all residential buildings, both newly built and existing [23].

The purpose of the article is to determine the effect of a vertical installation of the DWHR spiral heat exchanger on the amount of operating costs of the single-family building supply system for hot water, depending on the source of heat, as well as the number of residents and the shower duration. The purpose of the article is to also analyze the emission of carbon dioxide into the atmosphere for various hot water preparation systems and to determine the impact of the heat recovery system from graywater on the amount of carbon dioxide produced and released into the external environment.

\section{Installation variants}

For the analysis were adopted six different heating devices working for the needs of the single-family building supply system for hot utility water constituting the "A" variants. In addition, an alternative variant " $\mathrm{B}$ " was also adopted for each of them, in which the installation is also equipped with a DWHR heat exchanger. The list of variants accepted for the calculation is as follows:

- Variant 1A: installation with a capacitive electric heater,

- Variant 1B: installation with a capacitive electric heater and DWHR heat exchanger

- Variant 2A: installation with a gas boiler,

- Variant 2B: installation with a gas boiler and DWHR heat exchanger,

- Variant 3A: installation with a biomass boiler,

- Variant 3B: installation with a biomass boiler and DWHR heat exchanger,

- Variant 4A: installation with a heating oil boiler,

- Variant 4B: installation with a heating oil boiler and DWHR heat exchanger,

- Variant 5A: installation with a coal boiler,

- Variant 5B: installation with a coal boiler and DWHR heat exchanger,

- Variant 6A: installation with an air-to-water heat pump,

- Variant 6B: installation with an air-to-water heat pump and DWHR heat exchanger.

The installation uses a vertical "pipe in pipe" type heat exchanger - WTW Doutche from Itho Daalderop [24] with a length of $2015 \mathrm{~mm}$ and a diameter of $63 \mathrm{~mm}$. The device is constructed of two pipes - the inner one of a smaller diameter and the outer one of a larger diameter. The essence of the exchanger's operation is that the hot water, used in the shower, drains gravitationally to the sewerage system with the internal conduit, and the pressurized cold water flows in the space between the two lines. The flowing water is heated by taking in heat from the outgoing graywater. Pre-heated hot water is then directed partly to the hot water tank and partly to the mixing valve of the shower mixer. 


\section{Calculation methodology}

The calculation of the seasonal hot water demand for the accepted installation variants, which was the basis for estimating the annual operating costs, was made in accordance with the methodology included in the Ministry of Infrastructure and Development regulation, dated 27 February 2015, on the methodology for determining the energy performance of a building, or part of building, and energy performance certificates [25]. The calculations were carried out using the ArCaDiA-TERMO 6.6 computer program. Calculation of the amount of energy that can be saved by mounting a vertical heat exchanger on the graywater discharge from the shower, was carried out according to the model contained in publication [26]. The baseline data for calculations are summarized in Table 1.

Table 1. Data used for calculation.

\begin{tabular}{|c|c|}
\hline Parameter & Parameter value \\
\hline The number of occupants & $2,3,4,5$ persons \\
\hline Hot water temperature & $55^{\circ} \mathrm{C}$ \\
\hline Cold water temperature & $8{ }^{\circ} \mathrm{C}$ \\
\hline Daily hot water consumption for cooking & $2,5 \mathrm{~L} /$ person/day \\
\hline Daily hot water consumption for cleaning & $4 \mathrm{~L} /$ person/day \\
\hline Daily hot water consumption for washing the dishes & $7 \mathrm{~L} /$ person/day \\
\hline Daily hot water consumption in washbasins & $6 \mathrm{~L} /$ person/day \\
\hline Shower lenght, $L_{s h}$ & $4,7,10 \mathrm{~min} /$ person/day \\
\hline The temperature of the mixed water flowing out of the showehead & $39{ }^{\circ} \mathrm{C}$ \\
\hline Mixed water flow from the showerhead & $9 \mathrm{~L} / \mathrm{min}$ \\
\hline Efficiency of DWHR heat exchanger & $57,6 \%$ \\
\hline DWHR device, $x$ & 0,95 \\
\hline Coefficient of hot water loss in the cabin and pipes leading to the & \\
\hline
\end{tabular}

The variants of the installation were characterized to determine the efficiency of the hot water preparation system for each of them. The total average annual efficiency of the installation consists of: the efficiency of heat generation in the heat source, the efficiency of heat accumulation in capacitive elements, the efficiency of heat transfer to dredging points and the efficiency of heat utilization [25]. The total, average annual systems efficiencies accepted for the calculation are summarized in Table 2.

Table 2. Summary of the efficiency of systems which supply hot water.

\begin{tabular}{|c|c|c|c|c|c|c|}
\hline Variant & 1 & 2 & 3 & 4 & 5 & 6 \\
\hline Efficiency of system & 0,77 & 0,65 & 0,58 & 0,60 & 0,49 & 1,77 \\
\hline
\end{tabular}

Based on local price lists of media suppliers and fuel vendors, the unit prices of energy carriers were adopted, which made it possible to estimate the operating costs for each variant. The accepted prices are shown in Table 3.

The emission of pollutants into the atmosphere was estimated based on the indicators included in the ArCaDiA-TERMO program 6.6 - the module "Ecological effect". 
Table 3. Unit prices of energy carriers.

\begin{tabular}{|c|c|c|c|c|c|c|}
\hline Variant & 1 & 2 & 3 & 4 & 5 & 6 \\
\hline $\begin{array}{c}\text { Type of energy } \\
\text { carrier }\end{array}$ & $\begin{array}{c}\text { Electric } \\
\text { Energy }\end{array}$ & Natural Gas & Wood & Heating Oil & Coal & $\begin{array}{c}\text { Electric } \\
\text { Energy }\end{array}$ \\
\hline $\begin{array}{c}\text { Unit price } \\
\text { [eur/c.u.] }\end{array}$ & $\begin{array}{c}0,136 \\
\text { eur } / \mathrm{kWh}\end{array}$ & $\begin{array}{c}0,595 \\
\text { eur } / \mathrm{m}^{3}\end{array}$ & $\begin{array}{c}50,00 \\
\text { eur } / \mathrm{m}^{3}\end{array}$ & $\begin{array}{c}596,05 \\
\mathrm{eur} / \mathrm{m}^{3}\end{array}$ & $\begin{array}{c}214,29 \\
\text { eur } / \mathrm{kg}\end{array}$ & $\begin{array}{c}0,136 \\
\text { eur } / \mathrm{kWh}\end{array}$ \\
\hline
\end{tabular}

\section{Calculation results and analysis}

The calculated annual operating costs for all considered installation variants are presented in Table 4. Analyzing the "A" installation variants, the highest operating costs are observed in the case of heating water using an electric heater. They range from 304 eur/yr to 1358 eur/yr, depending on the number of users of the installation and the duration of the bath.

Table 4. Annual operating costs of accepted installation variants [eur/yr].

\begin{tabular}{|c|c|c|c|c|c|c|c|c|c|c|c|c|}
\hline \multirow{4}{*}{ 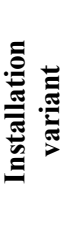 } & \multicolumn{12}{|c|}{ Number of occupants } \\
\hline & \multicolumn{3}{|c|}{2} & \multicolumn{3}{|c|}{3} & \multicolumn{3}{|c|}{4} & \multicolumn{3}{|c|}{5} \\
\hline & \multicolumn{12}{|c|}{ Shower lenght [min/person/day] } \\
\hline & 4 & 7 & 10 & 4 & 7 & 10 & 4 & 7 & 10 & 4 & 7 & 10 \\
\hline $\mathbf{1 A}$ & 304 & 425 & 547 & 452 & 635 & 817 & 601 & 844 & 1088 & 750 & 1054 & 1358 \\
\hline 1B & 219 & 306 & 393 & 325 & 456 & 586 & 431 & 605 & 779 & 538 & 755 & 972 \\
\hline $2 \mathrm{~A}$ & 162 & 226 & 289 & 240 & 335 & 431 & 317 & 445 & 572 & 395 & 554 & 713 \\
\hline $2 B$ & 125 & 173 & 221 & 184 & 256 & 329 & 243 & 339 & 436 & 302 & 423 & 544 \\
\hline 3A & 75 & 102 & 130 & 109 & 150 & 192 & 143 & 198 & 254 & 177 & 246 & 316 \\
\hline 3B & 60 & 82 & 104 & 87 & 119 & 152 & 113 & 157 & 201 & 140 & 195 & 249 \\
\hline $4 \mathrm{~A}$ & 165 & 230 & 295 & 245 & 342 & 439 & 324 & 454 & 584 & 403 & 566 & 728 \\
\hline 4B & 130 & 180 & 231 & 192 & 267 & 343 & 253 & 354 & 455 & 315 & 441 & 567 \\
\hline $5 \mathrm{~A}$ & 102 & 141 & 180 & 150 & 209 & 267 & 198 & 276 & 354 & 246 & 343 & 441 \\
\hline 5B & 85 & 117 & 149 & 124 & 172 & 220 & 163 & 227 & 291 & 202 & 282 & 362 \\
\hline $6 \mathrm{~A}$ & 136 & 188 & 241 & 200 & 279 & 359 & 265 & 370 & 476 & 329 & 461 & 594 \\
\hline $6 \mathrm{~B}$ & 51 & 69 & 87 & 73 & 100 & 127 & 95 & 131 & 168 & 117 & 163 & 208 \\
\hline
\end{tabular}

The most economical in terms of finances is heating the water with a biomass boiler. For this variant, operating costs range from 75 eur/yr to 315 eur/yr. The difference between the values obtained in variants $1 \mathrm{~A}$ and $3 \mathrm{~A}$ is therefore very large. In the case of variants "B" (with a DWHR heat exchanger), the highest operating costs were also obtained for the heat source - an electric heater, however, these values are lower by approximately $30 \%$ and amount to 219 - 972 eur/yr.

The annual savings resulting from the installation for hot water preparation in the DWHR exchanger per capita and depending on the duration of the bath are shown in Figure 1. The highest annual savings compared to the standard variant "A" were obtained when the heat source is an electric heater and air-to-water heat pump, which can result from the relatively 
high price of the energy carrier which in this case is electricity. The lowest value of annual savings per capita was obtained in the variant where the source of heat is a biomass boiler. The savings are greater, the longer the bathing time is, and thus hot water consumption is higher. When installing a DWHR heat exchanger at the outflow of used water from a shower to a sewage system, you can save an average of about 32 eur per person per year.

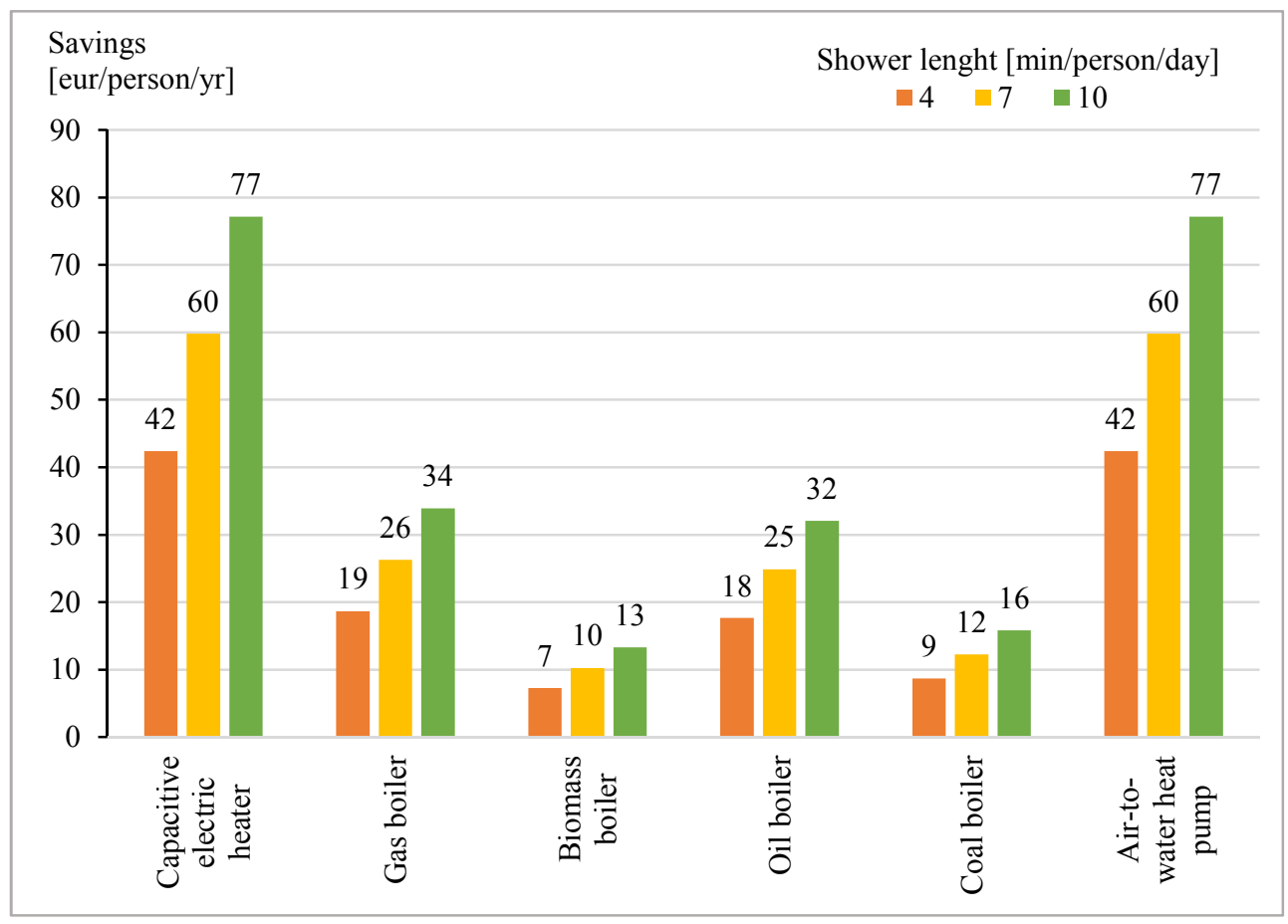

Fig. 1. Annual savings resulting from the installation of the DWHR exchanger per capita, depending on the duration of the bath [eur].

The emission quantities of fossil fuel combustion products such as $\mathrm{SO}_{2}, \mathrm{NO}_{\mathrm{X}}, \mathrm{CO}, \mathrm{CO}_{2}$ and dust, which were emitted into the atmosphere as a result of the use of hot water preparation installations for all variants, were also calculated. In the light of the legal acts concerning energy policy in the European Union [27], the reduction of carbon dioxide emissions is the most desirable as it increases the greenhouse effect, thus contributing to global warming [28], which is why the paper presents the results of calculations for this gas. Table 5 presents the calculated annual $\mathrm{CO}_{2}$ emission for each of the adopted installation variants. Depending on the input data, the production of carbon dioxide by the adopted hot water supply systems varies from $265 \mathrm{~kg}$ to $8124 \mathrm{~kg}$ per year. By far the lowest value of $\mathrm{CO}_{2}$ emission into the atmosphere was obtained in option $6 \mathrm{~B}$, where the heat source was an airto-water heat pump and the installation was additionally equipped with a vertical heat exchanger. It is worth noting that taking into consideration only the standard variants "A", the least amount of carbon dioxide released into the atmosphere is through the installation in which the heat demand for water heating is covered by the oil boiler (variant 4A), not a device classified as renewable energy sources - heat pump. This may be due to the fact that the heat pump for transferring the "free" energy from the bottom source requires a certain amount of electricity, whose production is characterized by relatively high $\mathrm{CO}_{2}$ emission rates. As a result of using the heating system, on average, per inhabitant, from 238 to $1630 \mathrm{~kg} \mathrm{CO}_{2}$ for variants "A" and from 132 to 1155 for variants "B" is emitted into the atmosphere during the year and depending on the source of heat. 
Table 5. The amount of annual carbon dioxide emissions for individual installation variants [kg].

\begin{tabular}{|c|c|c|c|c|c|c|c|c|c|c|c|c|}
\hline \multirow{4}{*}{ 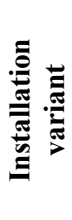 } & \multicolumn{12}{|c|}{ Number of occupants } \\
\hline & \multicolumn{3}{|c|}{2} & \multicolumn{3}{|c|}{3} & \multicolumn{3}{|c|}{4} & \multicolumn{3}{|c|}{5} \\
\hline & \multicolumn{12}{|c|}{ Shower lenght [min/person/day] } \\
\hline & 4 & 7 & 10 & 4 & 7 & 10 & 4 & 7 & 10 & 4 & 7 & 10 \\
\hline $1 \mathrm{~A}$ & 1818 & 2545 & 3273 & 2707 & 3799 & 4890 & 3596 & 5052 & 6507 & 4486 & 6305 & 8124 \\
\hline 1B & 1271 & 1791 & 2311 & 1906 & 2686 & 3466 & 2542 & 3582 & 4622 & 3177 & 4477 & 5777 \\
\hline $2 \mathrm{~A}$ & 552 & 762 & 972 & 809 & 1123 & 1438 & 1065 & 1485 & 1905 & 1322 & 1846 & 2371 \\
\hline 2B & 429 & 588 & 748 & 624 & 863 & 1102 & 819 & 1138 & 1457 & 1014 & 1412 & 1811 \\
\hline 3A & 855 & 1189 & 1523 & 1263 & 1764 & 2265 & 1671 & 2339 & 3007 & 2079 & 2914 & 3748 \\
\hline 3B & 680 & 943 & 1204 & 1000 & 1393 & 1787 & 1321 & 1845 & 2369 & 1641 & 2296 & 2951 \\
\hline $4 A$ & 499 & 688 & 876 & 729 & 1012 & 1294 & 959 & 1336 & 1712 & 1190 & 1660 & 2131 \\
\hline $4 B$ & 397 & 543 & 690 & 576 & 795 & 1015 & 755 & 1048 & 1340 & 934 & 1300 & 1666 \\
\hline $5 \mathrm{~A}$ & 932 & 1297 & 1662 & 1378 & 1925 & 2473 & 1824 & 2554 & 3284 & 2270 & 3183 & 4096 \\
\hline $5 B$ & 769 & 1068 & 1366 & 1134 & 1582 & 2030 & 1499 & 2097 & 2694 & 1864 & 2611 & 3358 \\
\hline $6 \mathrm{~A}$ & 773 & 1089 & 1405 & 1159 & 1633 & 2107 & 1545 & 2177 & 2810 & 1932 & 2722 & 3512 \\
\hline $6 B$ & 265 & 373 & 482 & 397 & 560 & 722 & 530 & 747 & 963 & 662 & 933 & 1204 \\
\hline
\end{tabular}

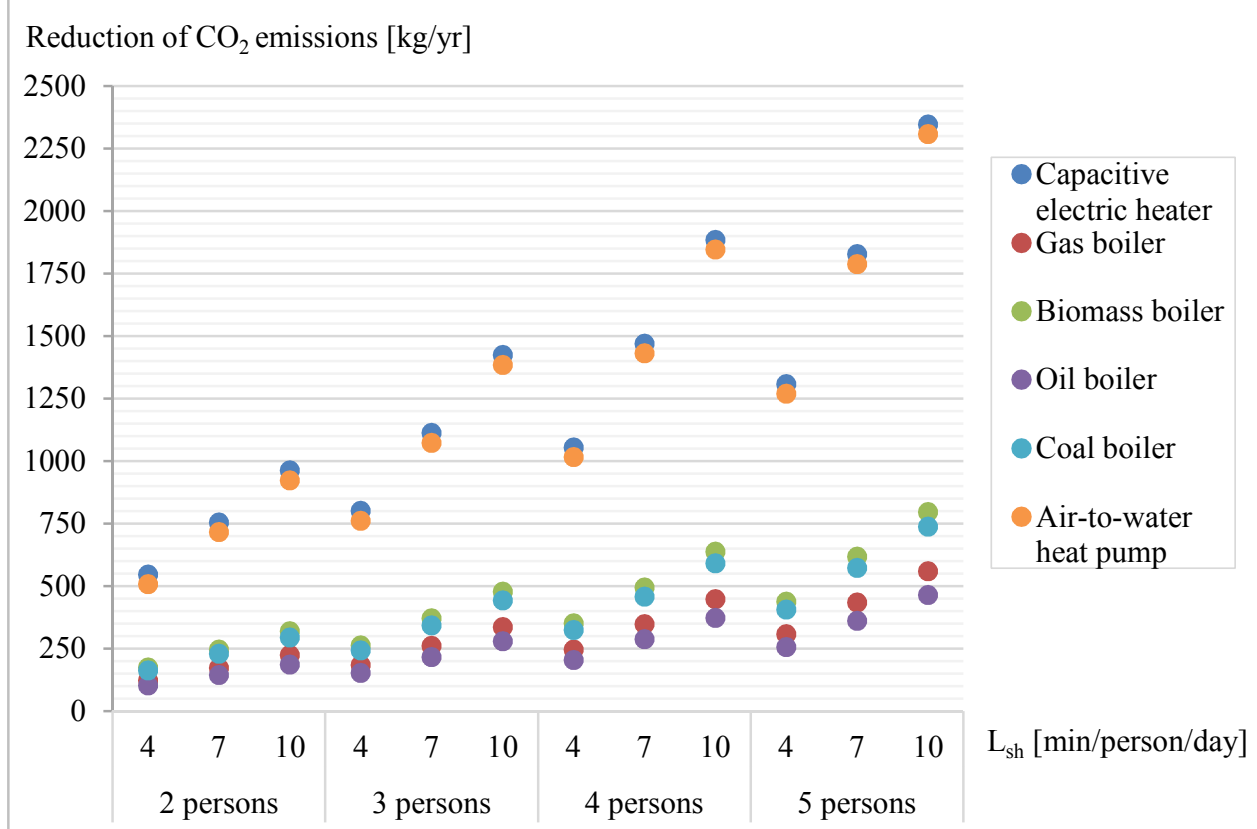

Fig. 2. Reduction of carbon dioxide emissions into the atmosphere $[\mathrm{kg} / \mathrm{yr}]$. 
The reduction of $\mathrm{CO}_{2}$ gas emissions during the year, resulting from the use of the installation for heat recovery from graywater is shown in Figure 2. As shown in the results from the calculations, this installation allows reducing the amount of dioxide released into the atmosphere by about $102 \mathrm{~kg}$ of $\mathrm{CO}_{2}$ with two inhabitants, a 4 minute shower duration and the energy carrier in the form of heating oil, up to $2347 \mathrm{~kg}$ of $\mathrm{CO}_{2}$ with 5 users, with a 10 minute duration for bathing in the shower and the energy carrier in the form of electricity. The most positive impact on the external environment understood as obtaining the highest reduction of carbon dioxide emissions through the installation of a heat recovery system from graywater is observed in variants 1 and 6, where the heat sources are respectively, electric heater and air-to-water heat pump, producing thermal energy using electric energy.

\section{Conclusions}

The annual operating costs of the domestic hot water preparation system depend on several parameters: system efficiency, the type of energy carrier, its calorific value and price, but first of all on the number of users of the installation and the volume of daily demand for hot water. Depending on the installation variant, between 51 eur and 1358 eur has to be spent annually for the preparation of domestic hot water. The range of values is very large, but it also results from the different number of inhabitants adopted for calculations and a different duration of bathing. On average, for each user installation, the annual cost of using the hot water supply system for variants "A" ranges from 36 eur to 272 eur and for variants "B" from 24 eur to 195 eur. The system of heat recovery from graywater allows for annual savings of $20-30 \%$. Calculated for each user of the installation, the annual operating costs of the hot water preparation system in the configuration with a vertical heat exchanger are lower by 32 eur.

The use of an installation equipped with a heat recovery system from wastewater not only positively affects operating costs, but it lowers expenses for the purposes of preparing hot usable water. The biggest advantage of this system, is however, the positive impact on the external environment. Reduced energy consumption from fossil fuels, reduces the emission of harmful compounds into the atmosphere, resulting in an improvement of the external environment. The article also calculates the annual emission of carbon dioxide into the atmosphere both for the standard variants "A" as well as the variants equipped additionally with the heat recovery system from wastewater "B". A comparison of these values allowed a determination of the possibility of reducing carbon dioxide emissions into the environment as a result of the installation of a DWHR exchanger. During the year, on average per capita, this value was from 51 to $112 \mathrm{~kg}$ of $\mathrm{CO}_{2}$, depending on the heat source variant.

The economic factor is the criterion most often taken into account when determining the selection of a particular heating system by an individual investor, including the costs incurred for the construction of installations, less often the operating costs, yet bearing in mind the current economic situation in the world and the progressive pollution of the natural environment, above all, ecological considerations should be kept in mind.

\section{References}

1. C.E. Wyman, Plant biotechnology for sustainable production of energy and coproducts, 66, 3-23 (2010)

2. T. Thielemann, S. Schmidt, J. P. Gerling, Int. J. Coal Geol. 72, 1-14 (2007)

3. A. Fiore, V. Naik, E. Leibensperger, J. Air Waste Manage. 65(9), 1159-1159 (2015)

4. N. E. Selin, S. Wu, K. M. Nam, J. M. Reily, S. Paltsev, R. G. Prinn, M. D. Webster, Environ. Res. Lett. 4, 044014 (2009) 
5. D. Słyś, J. Dziopak, Pol. J. Environ. Stud. 20, 743-53 (2011)

6. M. Starzec, J. Dziopak, Underground Infrastructure of Urban Areas 4, 181-191 (2018)

7. V. O. Harbul'akova, M. Zelenakova, M. Rysulova, A. Repel, D. Simonova, Environmental Processes - An International Journal, 4, 163-177 (2017)

8. K. Pochwat, D. Słyś, S. Kordana, J. Hydrol. 549, 501-511 (2017)

9. M. Starzec, J. Dziopak, D. Słyś, Underground Infrastructure of Urban Areas 4, 193200 (2018)

10. K. Pochwat, E3S Web Conf. 17, 00075 (2017)

11. V. V. Shalaj, A. G. Mikhailov, E. N. Slobodina, S. V. Terebilov, Procedia Engineering, 113, 287-291 (2015)

12. M. Śliwka, M. Pawul, W. Kepys, R. Pomykała, J. Ecol. Eng. 18, 216-225 (2017)

13. J. G. J. Oliver, G. Janssens-Maenhout, J. A. H. W. Peters, Trends in Global $\mathrm{CO}_{2}$ Emissions 2012 Report. JRC Background Studies. Available: edgar.jrc.ec.europa.eu/CO2REPORT2012.pdf (accessed December 2017)

14. A. Stec, A. Mazur, D. Słyś, E3S Web Conf. 22, 00168 (2017)

15. A. Stec, S. Kordana, D. Słyś, J. Clean. Prod. 151, 193-205 (2017)

16. M. Beccali, M. Cellura, S. Longo, F. Guarino, Sol. Energ. Mat. Sol. C. 156, 92-100 (2016)

17. E. Hervas-Blasco, M. Pitarch, E. Navarro-Peris, J. M. Corberan, Energy 127, 558-570 (2017)

18. S. Kordana, E3S Web Conf. 17, 00042 (2017)

19. S. Kordana, D. Słyś, E3S Web Conf. 22, 00085 (2017)

20. A. McNabola, K. Shields, Energ. Buildings 59, 44-49 (2013)

21. S. Torras, C. Oliet, J. Rigola, A. Oliva, Appl. Therm. Eng. 103, 670-683 (2016)

22. A. R. Mazhar, S.Liu, A. Shukla, Energies 11, 386 (2018)

23. C. M. Leidl, W. D. Lubitz, Technol. Soc. 31, 244-256 (2009)

24. Itho Daalderop Brochures, http://www.ithodaalderop.nl (accessed November 2017)

25. Journal of Laws of 2015, item 376, Regulation of the Minister of Infrastructure and Development of 18 February 2015 on the methodology for determining the energy performance of a building or part of a building and energy performance certificates

26. S. Fidewicz, Biblioteka Źródłowa Energetyki Prosumenckiej, Available: http://ilabepro.polsl.pl/spep/raporty/energetyka-odpadowa/Fidewicz\%20Sz. \%20Ciep\%C5\%82o\%20odpadowe\%20w\%20domu..pdf (accessed November 2017)

27. European Council Report 2014, Available: http://www.consilium.europa.eu/uedocs/ cms_data/docs/pressdata/en/ec/145397.pdf (accessed December 2017)

28. J. E. Szulejko, P. Kumar, A. Deep, KH. Kim, Atmos. Pollut. Res. 8, 136-140 (2017) 